\title{
Dynamic Land Resource Management in Mt. Kelud Area
}

\author{
Puspita Indra Wardhani \\ Doctoral Program, Faculty of Geography \\ University of Gadjah Mada, \\ Yogyakarta, Indonesia. \\ Corresponding email: poespita.indra@gmail.com \\ Junun Sartohadi \\ Faculty of Geography, \\ University of Gadjah Mada, \\ Yogyakarta, Indonesia. \\ Sunarto \\ Faculty of Geography, \\ University of Gadjah Mada, \\ Yogyakarta, Indonesia
}

\begin{abstract}
Area in the active volcano is blessed with abundant land resources. Mt. Kelud eruption in 2014 directly changes the arrangement of land resources. The changes in the land surface conditions must be balanced with the new management to enable the communities enjoying the benefits. The research has aim to identify the landform changes and to get an appropriate management in the dynamic land resource in active volcanic area. The research conducted through field survey method based on physical environment. The field survey proposes to identify the distribution of land resources. We interpret the distribution of land resources based on topographic map, land use/land cover data, and Landsat imagery. In deep interviews were done to get information about social life of the community, risk perception of Mt. Kelud eruption and benefits of Mt. Kelud eruption. The results showed that land resources in Mt. Kelud are dynamic due to the eruption. The dynamic occurs in the arrangements of land resources in the area of Mt. Kelud. The new arrangement of land resources consists of new landscape and new material. We found that the new resource has a high value for the local community welfare. For example, the local community in Mt. Merapi utilize te material and new landscape to improve their welfare. We offer integrated strategy to manage the new land resources. The integrated strategy manages the sustainability of the land resource and improves the community welfare.
\end{abstract}

\section{Keywords—Management, land resources, volcano}

\section{INTRODUCTION}

Volcanic eruption is a natural process. It can be observed directly through the yield of volcanic activity that it usually leaves scars in the form of cone volcanoes, caldera, lava flow, and material eruption (Carey, et al, 1996), (Sartohadi, et al, 2014). The volcanic eruption gives the regions with rich minerals and nutrient reserves in the soil (Schaeztl, et al, 2005). The eruption becomes very important process for environment. It becomes the most dominant natural processes in the Earth and affects the shape of the land surface (Cas, 2005). Volcanic eruption creates the dynamic environmental of Earth.

The volcanic eruption has consequence of the new arrangements of land resources. The eruption expels the material pyroclastic in surrounding volcanic area. The material eruption will pile on the land surface. It changed the configuration of landform in the volcano prone area. Mostly, the material eruption on the land surface had damaged the agriculture, plantation, tourism, and physical building (Horwell, C. J. and Baxter, P. J., 2006), (Stewart, et al, 2006), (Wilson, et al, 2011).

Mt. Kelud eruption on February 13, 2014 formed a new configuration in the land surface. The new configuration derived from the piled material in the surface. It created the new arrangement of land resources in the Mt.Kelud area. The new arrangements on land resources led to the emergence of a new morphology on the land surface (Emilia and Carmela, 1992). The new arrangement of land resources in Mt. Kelud becomes the potential resources to be developed.

New material and unique landscapes were formed posteruption of Mt.Kelud. The new material of Mt. Kelud typically is pumice. The pumice was spread over $15 \mathrm{~km}$ from the crater. It has a diameter from $15 \mathrm{~cm}-5 \mathrm{~mm}$ (Wardana, et al, 2014). The new landscape was formed post-eruption that has unique natural scenery and dramatic colored of dark and gray (Wilson, et al, 2011). It was attracted for some people who have memories of Mt. Kelud. The people were curious about the condition of Mt. Kelud increased the number of visitor of Mt.Kelud post-eruption.

The material eruption from Mt. Kelud has piled along the headwaters in Mt. Kelud. It became the main material for 
mining activities. The dominant material that is pumice less enthused by the sand miners despite abundant in Mt. Kelud area. The pumice has the character less powerful when used for building materials because of the lack of mineral silica rock and hollow structure. Therefore, the innovation was needed to process the pumice so it can be useful for the local community.

Mt. Kelud makes the surrounding environment is constantly changing. The dynamically physical environment in Mt. Kelud was affected by the level of volcanic activities of Mt. Kelud. Mt. Kelud has short period of eruption between 1530 years. Facing the dynamic environment, it needs strategy to manage the land resources. The land resources management must follow the environmental condition so it could use to improve the community welfare.

\section{METHOD}

The research was conducted through field survey method based on descriptively of the physical environment and sociocultural community. The field survey gathers information about the volcanic landform from the peak until volcanic footplain. The interpretation of topographic map used to identify the volcanic area through land surface of morphology analysis. The results of identification were combined with land cover or land use data through Landsat TM image interpretation to analyze the distribution of land resources. Arc GIS 10.3 was used to interpret the distribution of land resources. The physical survey also gathers information about volcanic disaster obtained from the literature and statistical data from the agencies and offices both local and central government.

Social field survey conducted to know about social conditions of communities especially their livelihood based on physical form. The Observations of the condition of social and cultural life of community was done through depth interviews with key persons. The key persons are The Elderly in Nglegok Village, The Headman of Sugihwaras Village, and The Regent of Blitar Regency. The interviews use open question about the community's livelihood, risk perception of Mt. Kelud eruption and benefits of Mt. Kelud eruption. The results of the study were presented descriptively by revealing the facts of the field that comes with an explanation according to existing theories.

\section{FINDING AND DISCUSSION}

\section{A. The Study Area of Mt. Kelud}

Mt. Kelud is a strato-volcano with crater lakes. It is located in the East Java. Mt. Kelud administratively sites in the three districts, they are Blitar, Kediri and Malang. The last eruption occurred on February 13, 2014. The eruption expels a pyroclastic material with a high column of $17 \mathrm{~km}$ that causes disruptions of community livelihood.

Mt.Kelud became one of the most active and dangerous volcanoes in Java (Kusumadinata, 1979), (Pratomo, 2006), (Badrudin, 1994), (Brotopuspito and Wahyudi, 2007). Mt. Kelud in the span of 95 years has been erupting up to 8 times (Table 1). Mt. Kelud eruption produced an irregular peak current. The crater of Mt. Kelud always shifts, proved by the findings of the lava plug over the area of Mt. Kelud. The peaks of Mt. Kelud were divided into Kelud (1731 m), Sumbing (1518 m), Kombang (1514 m), Lirang (1414 m), and Gajahmungkur (1488 m) (Brotopuspito, K, S., \& Wahyudi,,2007).

Mt. Kelud has the eruption characteristic of phreatomagmatic and continued with a short Plinian type (Badrudin, 1994), (Brotopuspito and Wahyudi, 2007) (Berger, et al, 2000). It usually releases short eruption (a few hours), although the eruptive period would be quite often between 1530 years (Berger, et al, 2000). The hazards of Mt. Kelud eruption comprise hot lahar (primary lahar) from water craters, pyroclastic flows, nuee ardente (pyroclastic surge), and the fallout of pyroclastic (Badrudin, 1994); (Brotopuspito, K, S., et al, 2007), (Zainnudin, 2009) The material products of Mt. Kelud eruption are typical pumice and scoria (Brotopuspito and Wahyudi, 2007), (Berger,et al, 2000)

Mt. Kelud eruption had always a major impact on the environment. Within the last 8 eruptions, It is at VEI 4 (Figure 1). Mt. Kelud eruption on a scale of VEI 2 in 1920 led to the lava plug while in 2007 led to the lava dome. Mt. Kelud eruption has the type of explosive eruption with the main threat came from the primary lahar (hot lahar from water crater), except in 2014, the threat is pyroclastic fall.

\section{TABLE I. HISTORY OF MT.KELUD ERUPTION EVER RECORDED.}

\begin{tabular}{|c|c|c|}
\hline Year & Damage and Fatalities & Type of eruption \\
\hline 1919 & $\begin{array}{l}5160 \text { fatalities } \\
1571 \text { victims of farm animals } \\
104 \text { villages were destroyed } \\
20.200 \mathrm{Ha} \text { lands were damaged }\end{array}$ & Explosive \\
\hline 1920 & - & - \\
\hline 1951 & $\begin{array}{l}7 \text { fatalities } \\
157 \text { injuries } \\
320 \text { Ha plantation and forest } \\
\text { were damaged }\end{array}$ & Explosive \\
\hline 1966 & 210 fatalities & Explosive \\
\hline 1984 & - & - \\
\hline 1990 & $\begin{array}{l}34 \text { fatalities } \\
\text { Land damaged in around } 2 \mathrm{~km} \\
500 \text { houses were damaged } \\
50 \text { school were damaged }\end{array}$ & $\begin{array}{l}\text { Phreatomagmatic } \\
\text { Plinian }\end{array}$ \\
\hline 2007 & - & Efusive \\
\hline 2014 & $\begin{array}{l}\text { Plantation, farm field, and } \\
\text { forest were damaged } \\
\text { Housing and tourism facility } \\
\text { were damaged }\end{array}$ & Explosive \\
\hline
\end{tabular}

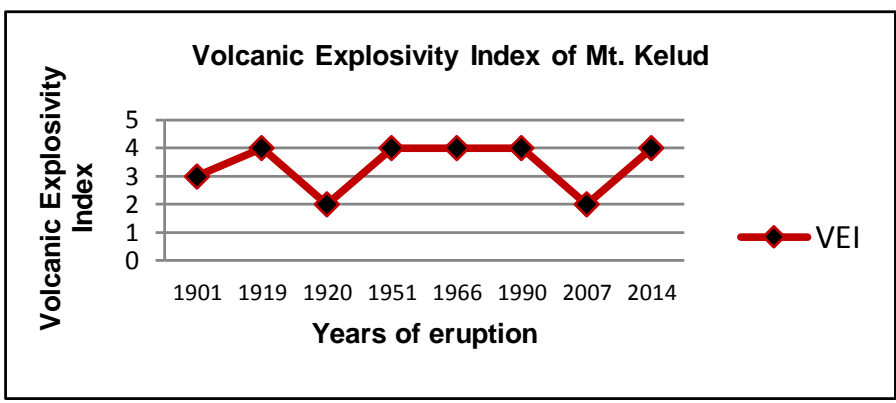

Fig. 1. Volcanic Explosity Index of Mt. Kelud Start from 1901. Adopted from Eruption in Indonesia by Global Volcanism Program, 2016. http://volcano.si.edu/search_eruption_results.cfm . 


\section{B. Land Configuration in Mt. Kelud Area}

- Before the eruption

Land area in Mt. Kelud has been long used by the community. It used for protected forests, plantations, tourism, agriculture, mining, and settlement. The Dutch government originally used the land for plantation estate. The increasing population inhabiting Mt.Kelud area, the land use activities develop into a variety of activities that can support the community's lives. The land use conditions in Mt. Kelud area presented in Figure 2.
Based on landscape conditions, Mt. Kelud area is divided into five i.e. peak, upper slope, middle slope, lower slope, and volcanic foot-plain. Each area has its own typical characteristics that distinguish from the other area. The peak of Mt. Kelud has been used for tourism activity. The peak of Mt. Kelud has the unique characteristic that is crater lake. The crater lake was changed into three times for last 25 years from crater lake after eruption 1990 to lava dome after eruption 2007 and crater lake again after eruption 2014. The type of Mt. Kelud eruption has affect to the shapes of Mt. Kelud crater.

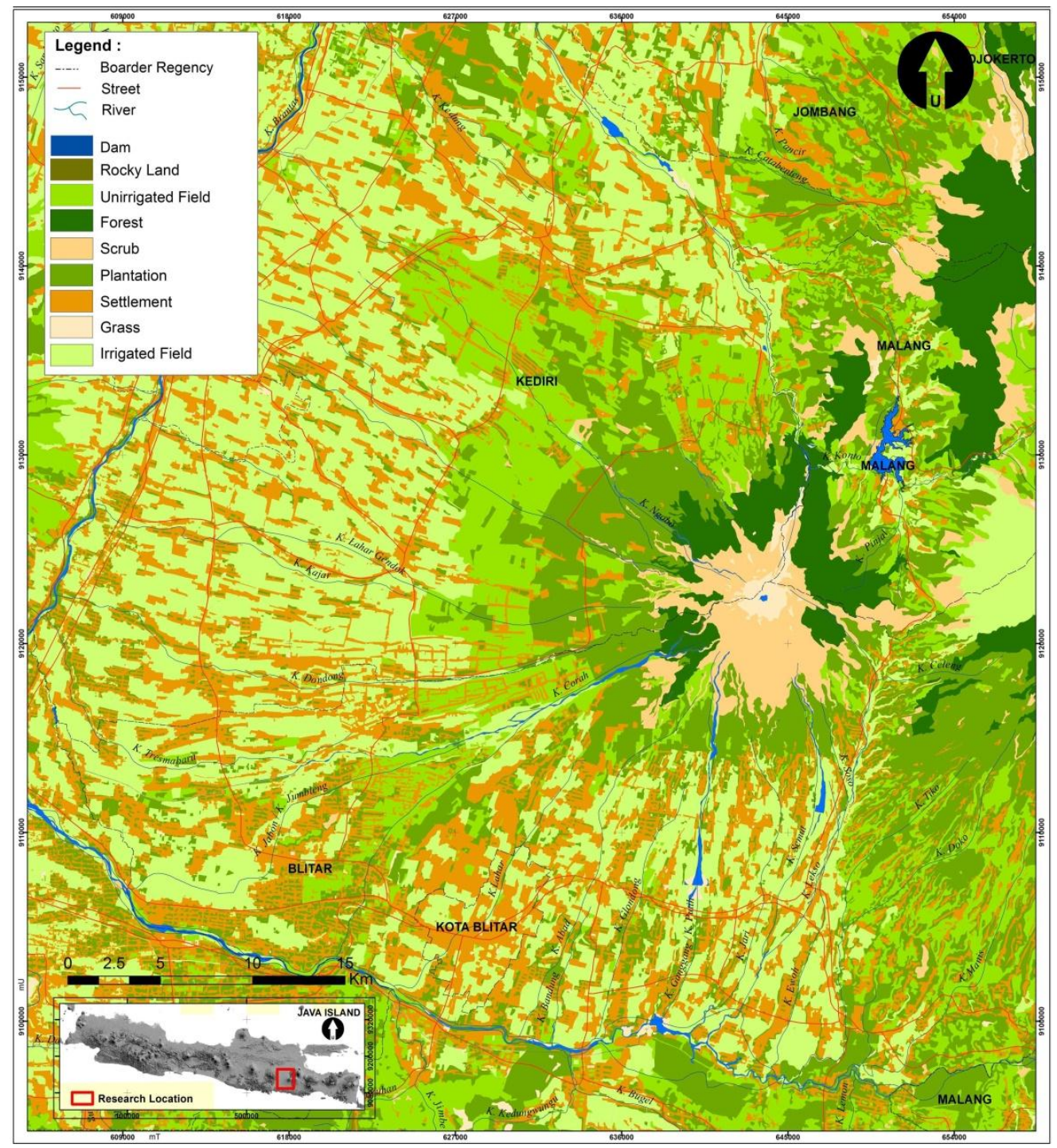

Fig. 2. Land Use Map of Mt.Kelud Area

The upper slopes of Mt. Kelud composed of materials such as tuffs, breccia, and pumice. It has deep valleys and sharp ridges. The upper slopes of Mt.Kelud used as a protected forest area. The materials in the upper slope dominated by unraveling material ranging from megaboulder to gravel. The soil in the upper slope cannot grow well due to the short duration of Mt. Kelud eruption at around \pm 25 years. The plants that can only live on the upper slopes are grasses and shrubs. The middle slope of
Mt.Kelud has wide ridge and rough undulating relief. It is composed by tuff-breccia and pumice that were easily weathered. In the middle slope can be found seepage in the flanks that supported the soil fertility (Rahmadana, et al, 2014). The intensive plantation has developed in the middle slope and followed by limited settlements area. The settlements usually can be found on the flat ridge. 
The lower slopes of Mt.Kelud has medium undulating with dominated by sandy material. The river valley began to appear in wider shape. The intensive and more varies activities of the community had begun in this area like plantation, sand mining, and settlement. The volcanic footplain has flat or sloping relief. The material in the volcanic foot-plain composed by sand, silt, and clay that transported by fluvial process located from the upper slopes areas. The volcanic foot-plain become the pocket area of lahar deposit material. The volcanic foot-plain had used for intensive agriculture and sand mining.
The Mt. Kelud eruption in 2014 gave the large impact to the surrounding area in Mt. Kelud. The largest impact from Mt. Kelud eruption is material eruption. Material eruption was piled in the land surface that formed the new land configuration in Mt. Kelud area. The material size from mega boulder until boulder can be found in the peak of Mt. Kelud. The Mt. Kelud area from peak until volcanic foot-plain was changed. The crater shape in the peak of Mt. Kelud was totally changed from lava dome to crater lake (Figure 3). The vegetation in the peak area was burned. The tourism facilities were totally damaged.

\section{- After Mt. Kelud Eruption}

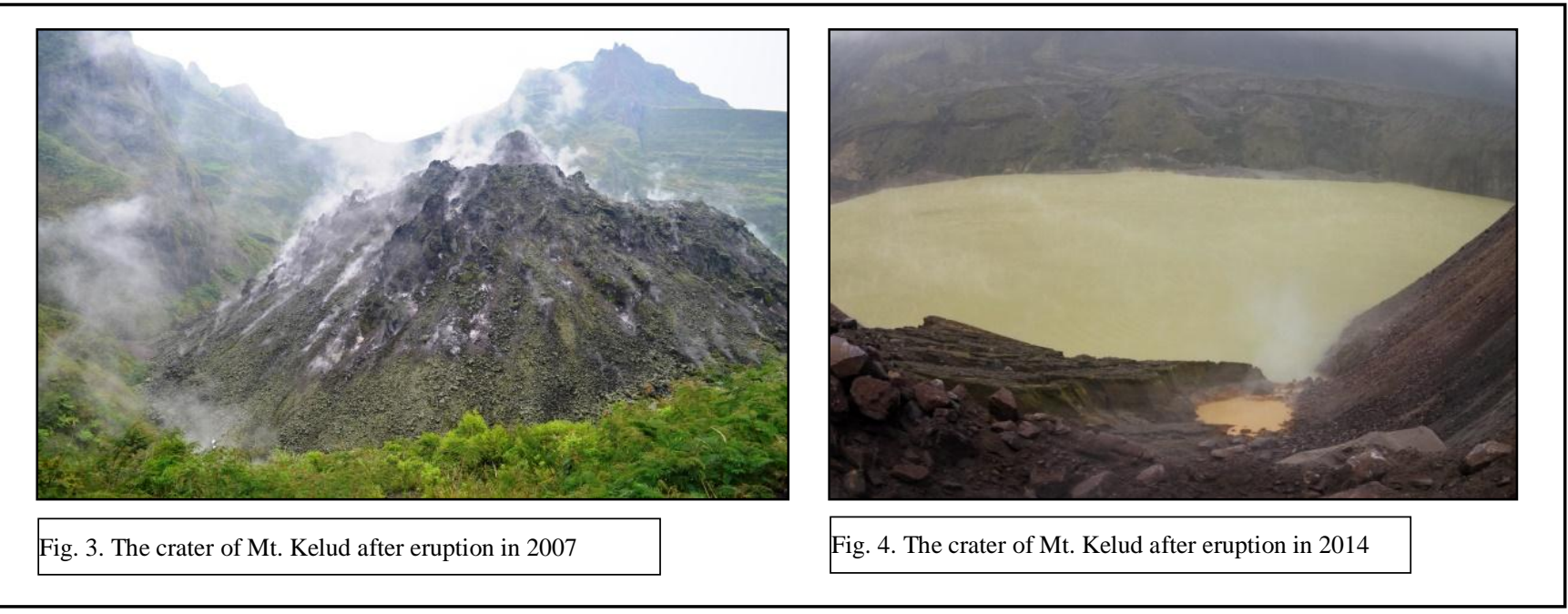

In the upper and middle slopes, the experiencing changed in the condition of relief. The valley was filled with material eruption, the forest in the upper slope was burned and the plantation estate in the middle slope was damaged due to the pyroclastic fall. The settlements in the middle slope were damaged especially in the rooftop due to pyroclastic fall. The material size ranging from medium boulder into gravel can be found in the surrounding area. In the lower slope, plantations and settlements partly damaged. The settlement was collapsed due to the weight of material deposit in the rooftop. The leaf of plant plantation was damaged due to the material fall. The plantation land surface was covered with material eruption. The material was dominated by pumice in ranging size from 3 $\mathrm{cm}-50 \mathrm{~mm}$, sand and ash. In the volcanic foot-plain, the sand and ash materials covered the surface. The rivers in the volcanic foot-plain become the lahar lane, which carries the threat of lahar flood to settlements in the surrounding area.

\section{The Community Perception about Mt. Kelud Eruption}

Observing from the case of Mt. Kelud eruption in 2014, the community does usual activities when the status of Mt. Kelud was alert. They have their own beliefs about the signs of Mt. Kelud eruption. They believe that there would be red-tailed monkeys coming down from mountain when Mt. Kelud eruption. Scientifically, the migration of animals down the mountain could be used as an indication of increasing temperature or possibly volcanic activity increase. The local knowledge helps the community to be wary of Mt. Kelud activity.

The community in Mt. Kelud area considered that Mt. Kelud eruption is harmless. They have past experience to face Mt. Kelud eruption. The Communities were already built the safety procedures to face Mt. Kelud eruption. For example the direction, the shelter, and the equipment. The government and the local community have held emergency response simulation before Mt. Kelud erupted.

\section{The Potential of Land Resources in Mt. Kelud}

The land in the Mt. Kelud area will always change due to the level activity of Mt. Kelud. The new land configuration in Mt. Kelud can bring new opportunities for the community in Mt. Kelud area. The new land configuration due to the eruption is not entirely a disaster since the volcanic eruption expelled the material that contains mineral and nutrient for living organism. The volcanic eruption is no longer of disaster but brings a benefit for the human life.

The new land configuration becomes new land resources that may provide opportunities for the community in the Mt. 
Kelud area. The new land resources are the natural landscape and the new material. Based on the (Marti and Ernst, 2005) the volcanic eruptions produce new materials that can be used for mining and (Gaudru, 2014) says that the volcanic area is an interesting tourist attraction. The community in Mt. Kelud area can manage the new land resources that can use as a strategy to dealing with the crisis period post-eruption.

For example, the case of Mt. Merapi post eruption, the local community opened the tourist attraction by selling touring the lahar river (Wijayanti, 2013) They gave name Lava Tour. Surprisingly, the new tourist attraction was attracting many tourists. The local communities have their livelihood again after eruption, and they can even rebuild their village after destroyed.
The natural landscape formed after the eruption can be potential as tourist attraction. The natural landscape offered the dramatic scenery colored of dark-gray and burnt forest. The natural landscape was interested by some people who have curious about the Mt. Kelud condition post-eruption. It is happened very rare and has a very limited time to enjoy the scenery. The scenery will be lost along with the growth of vegetation in Mt. Kelud area. The tourism activity posteruption can bring the huge benefit for the community if they can manage well. The community created a new livelihood by offering service such as selling food and drinks, provide parking, selling souvenirs and be a tour guide (Wijayanti, 2013) The tourism activity can help the recovery of the local economy community after the eruption.
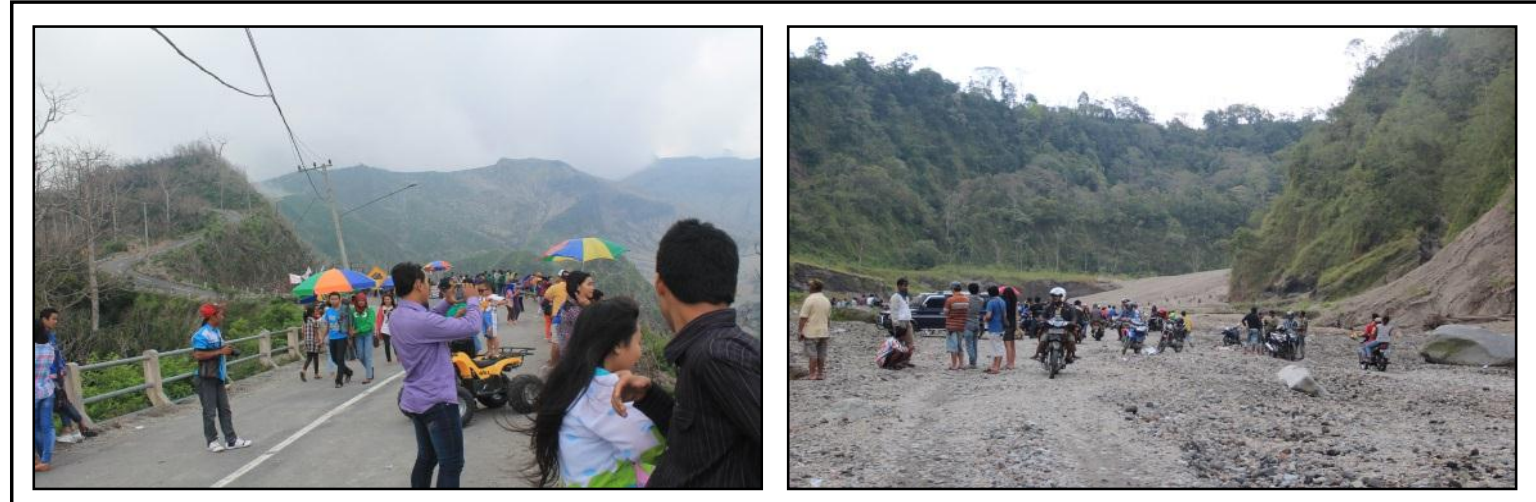

Fig. 5. The Mt. Kelud tourist attraction after eruption in 2014.
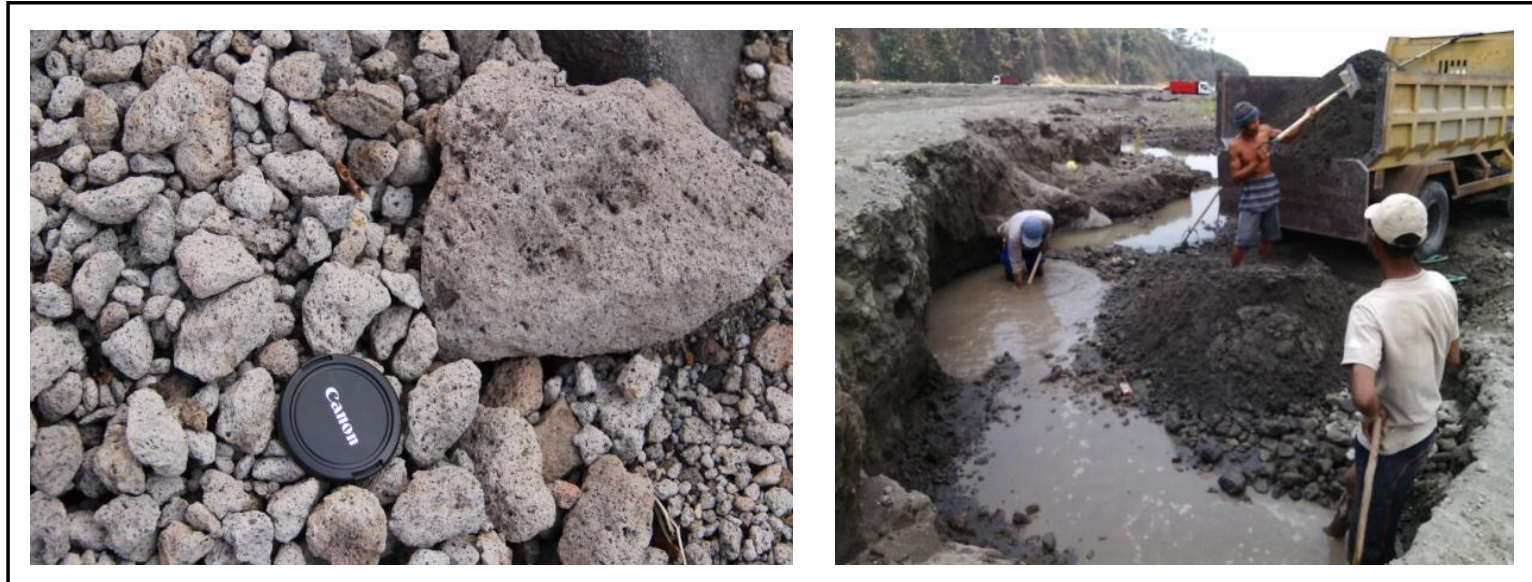

Fig. 6. The material eruption of Mt. Kelud becomes blessing for mining activity.

The new material from the eruption becomes a blessing for the sand miners. The material eruption is widely available in the rivers that disgorge in Mt. Kelud. It was dominated by pumice. However, pumice material not fully exploited yet because most of the community do not know to utilize. The community only takes the sand and stone that have a high price for building materials. In industrial sector, the pumice material has a high value as raw material and process into building construction, garments, and beauty care (Marti and Ernst, 2005)

\section{E. The Management of The New Land Resources in Mt. Kelud}

The learning from Mt. Kelud eruption in 2014, the desire of the tourism activity was large. The visitors just enjoyed the scenery or took the picture without any beneficial value for their knowledge. The tourism activity needs to manage well. The local government and the community can work together to improve the tourism activity. It can be improved by giving 
knowledge about volcano activity and disaster management for the visitors. The local community can be trained as tour guide. Therefore, both local community and visitor will take the benefit from Mt. Kelud tourism. Furthermore, the tourism area must save because the condition of tourism area post-eruption is not stable. The local governments need to arrange the SOP (Standard Operating Procedure) for safety procedure in the tourism area.

Post-eruption, the material eruption was available in the rivers that disgorge in the Mt. Kelud. The abundant material eruption has increased the sand mining activity. It was more intensive and uncontrolled. The impact of uncontrolled mining activity is environment and road damages. Accordingly, the sand mining activity must be managed. The amount of material is limited due to the period eruption of Mt. Kelud. The community needs to be used wisely so it can be utilized sustainable. The materials will be available again within a period of 15-25 years. In order to retrench the material eruption, it is needed to add value by processing the mining material. The miner can take less the material but can sell with high price. The material can be processing into brick or light concrete so the economic value of the material increased.

Among the land resources from the two activities, the tourism activity had the highest possibility to provide welfare for the community. It could also be combined with mining sector to improve the welfare of the community. Tourism sector lifts up the uniqueness area for land configuration in Mt. Kelud. Tourism sector combined with the mining sector produced natural attractions of the exploration of mining sites with a touch of adrenaline for visitors. Exploring the mining sites may need coorperation with the sand truck drivers as a type of transportation to enter the mining sites. Visitors are offered with a view of sand mining areas and processes of mining activity. The mining sector can earn extra income from tourist activities that can certainly improve the welfare of the community.

\section{IV.CONCLUSIONS AND SUGGESTIONS}

The volcanic eruptions are not always disastrous for human life. The eruptions bring many several benefit to improve human prosperity if we observe more deeply. The volcanic eruption has changed the land condition and has brought the new land resources. The new land resources are new material and new natural landscape. The new materials can be used for mining and the new landscape is an interesting tourist attraction.

We can get the benefit from the new land resources if we manage the new resources. The management of the new resources for examples, adding value by processing the mining material before we sell it, the new way to enjoy the landscape by exploring the mining site by truck. The new activities grow up after the volcanic eruption. It can be a benefit for the community because getting new livelihoods.

This research aims to open up new point of view in disaster field. Disaster is not only damage but also provide benefits for human life. Researchers take an example from the point of volcanic disasters of yet another disaster. In depth research still very necessary to enhance this research based on the viewpoint of multidisciplinary.

\section{ACKNOWLEDGEMENT}

The authors want to thank all colleagues, i.e. Alzaena Ulya Rusdimi, Anastasia Neni, Galih Aries, and Listyo Yudha Irawan for their assistance during data collection in the Mt. Kelud area. We thank to all informants for their permission of photo-audio recording during interviews and paper publication. We also thank the local authorities at district level in East Java Province (Blitar, Kediri and Malang) especially Bapak Rijanto mayor of Blitar district; the CVGHM (Centre for Volcanology and Geological Hazard Mitigation, Indonesia) especially Bapak Budi, Bapak Khoirul, and Bapak Kuncoro; and the BPBD (Regional Agency of Disaster Management).

\section{REFERENCES}

[1] Badrudin, M.,"Kelut Volcano Monitoring: Hazards, Mitigation, and Changes in Water Chemistry Prior to The 1990 Eruption". Chemical Journal, 1994, 28, pp. 233-241.

[2] Berger, M., Bernard, A., Sumarti, S., Sriwana, T., \& Sitorus, K, Crater Lakes of Java: Dieng, Kelud, Ijen. Excursion Guidebook IAVCEI Bali, 2000.

[3] Brotopuspito, K, S., \& Wahyudi, "Erupsi Gunungapi Kelud dan Nilai-B Gempabumi disekitarnya", Berkala MIPA, 2007, Pp. 47-56.

[4] Carey, S., Sigurdson, H., Mandeville, C.,Bronto, S, "Pyroclastic Flows and Surges over Water: an Example from the 1883 Krakatau Eruption", Bull Volcano, 1996, Vol. 57, pp. 493-511.

[5] Cas, Super Volcanoes Greatest Hazard on Earth, 2005. http://monash.edu/news/releases/show/264 (Accessed October 16 ${ }^{\text {th }}$, 2016).

[6] Emilia, P., dan Carmela, D, Forest in Changing Environment on The Etna Volcano, Netherland: Springer Netherlands, 1992.

[7] Gaudru, Henry, "Volcano Tourism: The Effect of Erupstions dan Disasters", Springer, 2014, pp. 337-350.

[8] Horwell, C. J., dan Baxter, P. J., "The Respitory Health Hazards of Volcanic Ash: a Review for Volcanic Risk Mitigation”, Bull Volcanol, 2006, DOI 10.1007/s00445-006-0052-y.

[9] Kusumadinata, K, Data Dasar Gunung Api Indonesia. Dit. Vulk., Bandung, 1979

[10] Marti, J. dan Ernst, G.J., Volcanoes and The Environment, Amerika: Cambridge University Press, 2005.

[11] Pratomo, I., “ Klasifikasi gunungapi aktif Indonesia, studi kasus dari beberapa letusan gunungapi dalam sejarah”, Jurnal Geologi Indonesia, 2006, Vol. 4, pp. 209-227.

[12] Rahmadana, A. D.W., Sartohadi, J., Munawaroh, Kajian Bentang Sumberdaya Lahan Gunungapi Kelud, in Pengelolaan Bencana Kegunungapian Kelud pada Periode Krisis Erupsi 2014, Editor by Sartohadi, J. \& Pratiwi, E. P., Yogyakarta: Pustaka Pelajar, 2014.

[13] Sartohadi, J., Sianturi, R., Rahmadan, A., Maritimo, F., Wacano, D., Munawaroh, Suryani, T., Pratiwi, E., Bentang Sumberdaya Lahan Kawasan Gunungapi Ijen dan Sekitarnya, Yogyakarta: Pustaka Pelajar, 2014.

[14] Schaeztl, R., Danerson, S., Soils: Genesis and Geomorphology, Cambridge: University Press, 2005.

[15] Stewart, C., Johnston, D., M., Leonard, G. S., Horwell, C. J., Thordarson, T., Cronin, S.J., "Contamination of Water Supplies by Volcanic Ash Fall, a Literatur Review and Simple Impact Modelling”. J. Volcanol Geotherm Res, 2006, Vol. 158, pp296-306.

[16] Wardhana, G. M. K., Maritimi, F., Maulana, E., Ammarullah, A., Pemetaan Daerah Rawan Jatuhan Material Piroklastik: Kasus Erupsi Gunungapi Kelud 2014, in Pengelolaan Bencana Kegunungapian Kelud pada Periode Krisis Erupsi 2014, Editor by Sartohadi, J., \& Pratiwi, EP., Yogyakarta: Pustaka Pelajar, 2014. 
[17] Wijayanti, Anastasia R.W., "Perubahan Pekerjaan Masyarakat sebagai Akibat dari Bencana. Studi Kasus: Kawasan Wisata Volcano Tour Gunung Merapi Desa Umbulharjo, Kecamatan Cangkringan, Kabupaten Sleman”, Jurnal Perencanaan Wilayah dan Kota, 2013, Vol. 24, Pp. 19 -34 .

[18] Wilson, T. M., Stewart C., Daniels, V. S., Leonard G. S., Johnston D. M., Cole J. W., Wardman J., Wilson G., Barnard S. T.(2011). "Volcanic Ash Impacts on Critical Infrastrukture", J. Phys. Chem. Earth, doi:10.1016.

[19] Zaennudin, A., "Prakiraan Bahaya Erupsi Gunung Kelud". Bulletin Vulkanologi dan Bencana Geologi, 2009, Vol. 4, pp.1-17. 